\title{
Anusocratie? Freemasonry, sexual transgression and illicit enrichment in postcolonial Africa
}

\author{
Peter Geschiere and Rogers Orock
}

\begin{abstract}
Introduction ${ }^{1}$
Recently, Cameroonians, ever inventive in neologisms, have surprised the world with a new term: anusocratie. ${ }^{2}$ It has become a key term in the 'moral panic' haunting the country since the turn of the century about a supposed proliferation of 'homosexuality'. As elsewhere on the continent, such a proliferation is often seen as the result of colonial and postcolonial impositions. What is striking is that people make a direct link with illicit forms of enrichment, and that the anus - that is, anal penetration - is attributed a key role in this. Cameroon offers a quite special variant of such interpretations because many people both the press and 'radio trottoir' (pavement radio) - explicitly relate this to the country's elite being deeply involved in secret associations of Western provenance: Freemasonry, Rosicrucianism and the Illuminati. Following an association - notably current in francophone contexts - of Freemasonry with same-sex practices, Cameroonians speak of les pédés de la République. ${ }^{3}$ The message seems to be
\end{abstract}

Peter Geschiere is Emeritus Professor of Anthropology at the University of Amsterdam. Email: p.1.geschiere@uva.nl

Rogers Orock is a senior lecturer in anthropology at the University of the Witwatersrand, Johannesburg. Email: Rogers.Orock@wits.ac.za

${ }^{1}$ This article is part of our joint project on 'Freemasonry, decolonization and homophobia in Cameroon and Gabon - postcolonial imaginaries of sexuality and illicit enrichment'. All translations of French and German texts are ours.

${ }^{2}$ We translate this French term as 'anusocracy'. The term seems to come from Yaoundé, the capital of Cameroon and the main seat of its political-administrative elite. The first mention we could trace is from the article that accompanied one of the notorious lists published in 2006 by the Yaoundé-based newspaper L'Anecdote to denounce prominent homosexuals among the national elite (L'Anecdote 25, 25 January 2006; see below on l'affaire des listes marking a sudden intensification of homophobia in the country). Subsequently, the term was mentioned in various academic publications (Ndjio 2012; Awondo 2012). There are also references to anusocracy in popular music. 'The sun shines for all; we each have a chance, so why bring down your pants to be appointed to a post of director?' (translation from French) asks Ntoumba Minka in his song 'Sexy Mackéro' (2008, MPS Records) on an album with the same title. Similarly, Valsero, a young Cameroonian hip-hop artist who opposes Biya's regime, deplores the state of the country and the misrule of its elite: 'It is so hard to be young in Rio dos Camarões [Portuguese name for Cameroon] if you are not the child of the rich, homosexual, a cop or a politician' (translation from French) (General Valsero, 'Ce Pays Tue Les Jeunes' on the album Politikement Instable, 2008, MOG Records). A problem with 'anusocracy' as a term is the 'o' in the middle, which makes no sense grammatically. Apparently, the word was forged as an ironic counterpoint to democracy/démocratie, since 1990 a much discussed concept in Cameroon. In recent discussions on Facebook in Gabon, people speak rather of anustocratie. Here, the middle ' $t$ ' makes no sense either in Latin; apparently this alternative form is based on aristocratie (aristocracy).

${ }^{3}$ On the equation of Freemasonry with same-sex practices in Cameroon, see Orock and Geschiere (forthcoming) and also Ndjio (2012) and Abega (2007a). This association of a

(C) International African Institute 2020. This is an Open Access article, distributed under the terms of the Creative Commons Attribution licence (http://creativecommons.org/licenses/by/4.0/), which permits unrestricted reuse, distribution, and reproduction in any medium, provided the original work is properly cited. 
clear: since Freemasonry was a colonial imposition, homosexuality has also been introduced from the outside and is a colonial product. This explanation has specific consequences. Since it would be the elite in particular who had been corrupted by such colonial practices, denunciations of homosexuality in Cameroon are an attack from below, from society on the state, rather than the other way around (as elsewhere in Africa; see Nyeck 2013). Especially since 2006, the state elite have reacted against such suspicions by unleashing a witch hunt against 'homosexuals' in order to distance themselves from such accusations.

For many Cameroonians, but certainly not for all - there are other voices ${ }^{4}-$ this link between homosexuality, Freemasonry and illicit enrichment has become selfevident. However, in this article we hope to show that a further unravelling of this conceptual knot is both worthwhile and urgent since it opens up wider perspectives on what is at stake in the moral panics over homosexuality that have erupted in many African countries over the last few decades. The obvious focus for such further analysis is the link with illicit enrichment, condensed in the image of the anus as a source of wealth - hence 'anusocracy'. In current debates on Africa as a 'homophobic continent' - whether confirming this stereotype or questioning it - this association with illicit enrichment gets little attention. Nor does it figure in the classical Western texts on homosexuality. For instance, Freud (1905), in his stocktaking of its aspects in Drei Abhandlungen zur Sexualtheorie (Three Essays on the Theory of Sexuality), does not mention the link with enrichment. But in Africa it seems to be quite common.

The aim of this article is to show that this image of the anus as a source of wealth is not just another exuberant illustration of Pliny the Elder's old saying ex Africa semper aliquid novi (out of Africa, always something new). Rather, it articulates important concerns about inequality in changing contexts and how to deal with them. A first way to disentangle this association is to historicize it. In this, the Cameroonian case is of particular interest, since, as Patrick Awondo (2019) - a Cameroonian colleague who had the courage to address these sensitive issues from inside the country - has already signalled, present-day imaginaries about Freemasons practising transgressive forms of sexuality in order to enrich themselves are reflected in one of the very first ethnographies on Cameroon: namely, in the work of Günther Tessmann. Tessmann began his research in what is now South Cameroon in 1904, just after the Germans began to establish their control over this region. A notion that keeps coming up in his classic monograph Die Pangwe (1913), especially about the Fang, is biang akuma - the medicine of wealth - which, to Tessmann's own surprise, turns out to be directly related to same-sex practices. Following up this link led us into interesting complications. Clearly, it is too easy to oppose this biang akuma as some sort of

\footnotetext{
Western esoteric society (Freemasonry) with allegations of same-sex practices is certainly not limited to this country in Africa. See, for instance, the recent attack on pop star Rihanna in Senegal, just before her visit to the country in early 2018. In an interview with Jeune Afrique, Cheikh Oumar Diagne alleged that she was a member of the Illuminati (once a dominant secret society from Bavaria, now said to be 'a branch of Freemasonry') and 'therefore' she was sure to use her visit for propagating homosexuality (Jeune Afrique, 1 February 2018; The Guardian, 7 August 2018). Since Dan Brown's fictional Angels and Demons (2000), the Illuminati have become a true obsession in popular culture in Africa as well as elsewhere.

${ }^{4}$ See Awondo et al. (2012).
} 
'traditional' image of homosexuality to the current link to Freemasonry as a colonial or even a 'modern' version. For one thing, Tessmann's perspective was directly influenced by the ideas of Magnus Hirschfeld and others that were causing a scandal in Berlin at the time he left for the field. This historical link therefore helps show that the triangular imaginary of Freemasonry, witchcraft and homosexual practices as the secret behind the spectacular forms of enrichment that mark present-day relations in Cameroon developed over time in the context of an ongoing articulation of local and imported conceptions. 'Anusocracy' can thus be read as a new variant of an older moral discourse on illicit wealth.

Another lead for analysing this triangle is its generality in present-day Africa. It serves all too well for denouncing the staggering new inequalities that developed so quickly after independence all over the continent. Many studies emphasize the consumerist drive of the new African elites and their preference for imported goods. ${ }^{5}$ Lately, this has become even more grating because of increasing disappointment with the results of development, the mantra of the first decades of independence. Often, it is not the new elite's ostentatious consumption per se that is seen as the problem. A current comment on such consumerism in Cameroon is 'Oui, oui un Grand n'est pas un petit [Yes, yes, a big man is not an ordinary man]'. In other words, un Grand has to show off. The problem is rather that this accumulation of wealth is seen more and more as unproductive as it is not redistributed. People who do not share have always been easily accused of witchcraft, and this applies most poignantly to the postcolonial elites' staggering forms of accumulation. Apparently, people now easily make a link with same-sex practices, which are also seen as shocking because they are not geared towards reproduction. It is in this context that the anus is emerging in many parts of Africa as a focal point in articulating wealth and sexuality, both in popular rumours and in academic literature. As one of our interlocutors put it: 'The anus is rising.' 6

Still, the question remains: why does the anus take centre stage in moral attacks on illicit enrichment? It may be tempting to explain these rumours by reducing them to political-economic issues, but it is clear that sexuality plays a role of its own here. Two of the continent's most visionary thinkers, Cameroonian historian/philosopher Achille Mbembe (2010) and Gabonese anthropologist Joseph Tonda (2016), recently advanced more general interpretations of this linking of the anus to wealth. It is notable that their interpretations of such 'anusocracy'

\footnotetext{
${ }^{5}$ See, for example, Warnier (1993), Moore and Sanders (2001), Falola (2003) and Nuttall (2004).

${ }^{6} \mathrm{Cf}$. Charles Gueboguo (2009), who was already writing in 2009 on Cameroon about 'the homosexualization of upward social mobility [l'homosexualisation de l'ascension sociale]', adding that 'the behind [le derrière] ... has become a privileged site of domination'. Christophe Broqua generalized this insight: 'if homosexuality is developing in sub-Saharan Africa, it is because it allows one to become rich' (2009: 61). Of course, homosexual intercourse is much more variegated than just anal intercourse, in Cameroon as elsewhere, but the anus is central in the link people make with enrichment - hence our focus. Another limitation is that this linking of the anus with enrichment concerns anal penetration between men. Yet, as one of the reviewers for Africa remarked, 'women have anuses too'. Porn sites suggest that all over Africa there is also growing interest in cross-sex anal intercourse: Georges Meiu (forthcoming) has written on women in Kenya complaining about men increasingly preferring anal penetration, and in Cameroon there are stories about women experimenting with anal penetration by male partners as an interesting alternative. However, anusocracy as a path to riches is always associated with intercourse between men, hence the (unfortunate) gender bias of this article.
} 
seem to have quite different implications. Mbembe (2010: 213, 219) sees it as a new variation of a scheme that haunts witchcraft fantasies in general: the image of powerful witches (mostly elders) feeding on the life force of their younger dependants (régénération d'une virilité déclinante). Thus, anal penetration of young men seems to be the ultimate phallocracy, fortifying le Grand and emptying his victims. Tonda, however, inspired by Deleuze and Guattari's reflections on the 'capitalist anus', seems to relate it to the Fanonian nightmare of an 'impotent' African bourgeoisie. In Tonda's examples (2016: 132), it is elite persons who allow themselves to be penetrated, and thus robbed of their life force. Such variations highlight the volatility of the imaginary relating to anal penetration and wealth. Apparently, this link suggests all sorts of different possibilities.

An even greater challenge is to try to see whether 'queer studies', as developed in the West since the last quarter of the twentieth century, can offer any inspiration in understanding the special role of the anus in African discourses. Indeed, the anus takes centre stage in two of queer studies' foundational texts: Mario Mieli's Towards a Gay Communism (2018 [1977]), with the characteristic battle cry 'I keep my treasure in my arse, but it is open to everybody'; ${ }^{7}$ and American literary theorist Leo Bersani's paper with the challenging title 'Is the rectum a grave?' (2009 [1987]). Of course, the African context is very different, and so is the tenor of the discourses involved. But we hope to show that this confrontation with queer theory can help bring out another layer in the African discourses, one that is less homophobic and more linked to special forms of desire.

Clearly, unravelling the epistemological knot of Freemasonry, homosexuality and illicit enrichment that is captivating present-day Cameroon clearly demands visiting domains that seem to be far apart. So we ask for the reader's indulgence. Trying to understand why these mystical imaginaries around the anus acquired such force in Africa in recent times opens up unexpected perspectives.

\section{The rise of 'anusocracy': situating a moral panic}

Much has been written recently about the sudden intensification of popular concerns with a supposed proliferation of homosexuality in Cameroon, and the distinctive trajectory of the politicization of this issue in the country (see, for example, Awondo 2012; 2019; Awondo et al. 2012; Nyeck 2013). From as early as 2000 there were signs that the authorities were taking the criminalization of same-sex practices more seriously than before. ${ }^{8}$ But the Christmas sermon of Archbishop Tonye Bakot in 2005 is generally seen as a turning point. His Excellency attacked the elite - many of whom (including the president of Cameroon, Paul Biya, and several of his ministers) were present at the mass for sodomizing young men. This immediately drew considerable attention in the

\footnotetext{
7'Il mio tesoro lo conservo in culo, ma il mio culo è aperto a tutti.'

${ }^{8}$ See also Gueboguo (2006) and Corey-Boulet (2019). In Cameroon, such criminalization was only effected after independence (1960). As in all French ex-colonies, same-sex intercourse was not mentioned as a criminal offence in the laws the new state inherited from its former metropolis. It was only in 1972 that 'homosexuality' was criminalized by a presidential decree (Ordinance 347 signed by Ahmadou Ahidjo). In 2010, this ordinance was replaced by a special law passed by Cameroon's National Assembly (law no. 2010/012 of 12 December 2010).
} 
press (see, for instance, Mbembe 2005). Within two months this was followed by the affaire des listes already mentioned (see note 2), with several newspapers publishing lists of 'suspected' or even 'prominent' homosexuals, targeting leading figures in government and other areas of public life (including in the arts and sport). These accusations gained traction in public discourse and clearly upset the elite, generating several lawsuits.

Since 2005, the subject has remained of vigorous interest in the Cameroonian public space and animates passionate commentary in the media over what is at stake, which elite figures are the homosexuals, and their connection to power. Religious leaders, in particular those of the Catholic Church, have been the most influential in encouraging this moral panic. For them, homosexuality is part of a broader, international conspiracy against the 'traditional' view of the family and is causing a 'crisis' in the heterosexual family. ${ }^{9}$ Equally striking is the linking of 'witchcraft' imaginaries in Cameroon with both 'homosexuality' and illicit enrichment. Remember what was noted before about the link people make between non-reproductive sexualities and unproductive, non-redistributed wealth. As Mbembe already remarked in December 2005 when these explosive accusations were emerging, Cameroon is a country where the social imaginary remains deeply embedded in materiality - a 'marked taste for lecherous living' - and in struggles for 'raw' material consumption. He added that, in such circumstances, people are 'profoundly attached to superstition, fetishism, and magic'. ${ }^{10}$

A good example of this was the widespread allegation that regional elites in the North-West hired 'imported witchdoctors' from Nigeria during the restructuring of the ruling Cameroon People's Democratic Movement (CPDM) party in 2015. One of them was accused of having 'satisfied his carnal urges on a male child' and so he was arrested and interrogated by the local Gendarmerie. ${ }^{11}$ There, it was claimed, he confessed to sodomizing the young boy as part of his ritual activities to fortify his Cameroonian client, a female politician vying for the leadership of the women's wing of the regional chapter of the ruling party. Even though people referred to the 'witchdoctor's carnal urges', the underlying frame of interpretation was that the abuse of the young boy was a ritual crime meant to magically empower his client. There is a direct link here to Archbishop Tonye Bakot's accusatory Christmas sermon of December 2005, when he warned that in Cameroonian society 'the most important value is material possessions and power', so that 'the assassination of young children for the purposes of drinking their blood and eating their organs becomes an acceptable value'. ${ }^{12}$

Such powerful denunciations of the elite's pursuit of material enrichment by magical means are supported by dramatic events that seem to be all too real. Since 2005, President Paul Biya has launched an anti-corruption campaign with the official codename Opération Épervier (Operation Sparrowhawk). In practice, this campaign brought about the selective prosecution of Biya's former allies

\footnotetext{
${ }^{9}$ In 2015, Cameroonian Cardinal Christian Tumi declared: 'Homosexuality is a crime against humanity; it is not only a plot to destroy the family but also the existence of the human race' (L'Effort Camerounais, 25 March 2015, pp. 6-7; 24 June 2015, pp. 6-7; 22 July 2015, p. 5).

${ }^{10}$ See Mbembe (2001: 1061; 2005: 3); see also Geschiere (1997) and Roxburgh (2019: 91).

11 'North West CPDM reorganization goes deadly: imported witchdoctors swing into action', Eden, 17 August 2015, p. 1, 7.

${ }^{12}$ Le Messager, 27 December 2005, p. 11.
} 
turned political enemies and is therefore seen by many as a political 'witch hunt'. More than two dozen former ministers or high-level cabinet officials and directors of public corporations now languish in the notorious Kondengui Prison in Yaoundé. The arrest, trials and transport to the prison of these former men of wealth and power were marked by a spectacular display of both their crimes and their fall from Biya's grace. A prominent example was the case of a recent victim of this campaign, Edgar Alain Mebe Ngo'o. After serving as Biya's Director of the Civil Cabinet (1997-2004), he was elevated to powerful ministerial positions in national security (2004-09), defence (2009-15) and, less importantly, transport (2015-18). After his fall from public office in March 2018, people automatically assumed that he was under investigation for financial crimes during his long stay in government. In March 2019, through the type of 'intense news reporting' that is typical of the newly created and very pro-government private TV station Vision4, Cameroonians could follow in detail the drama of his arrest by the police. ${ }^{13}$

What gave this arrest particularly dramatic overtones was that the story was backed by video clips, showing that the former minister had enriched himself not only with a fleet of expensive cars, sprawling mansions across the capital city and tailor-made suits from Europe worth thousands of euros each, but also by amassing euro notes in one of the rooms of his house, which was full of money. One of the clips (probably faked but generally believed since it fitted so well in the Cameroonian context) showed the room packed with money - as unproductive as it could be - but also traces of an attempt to burn it. Comments attributed this to his wife (who was also arrested) attempting to destroy this mountain of evidence. When they were both led into Kondengui Prison (separately, of course), they were jeered at by onlookers like suspected thieves. Some of the onlookers were so enraged that they ran after Madame Mebe Ngo'o to lift up her dress, exposing her backside. This shaming (and also shameful) spectacle reminds elites in Biya's system of how precarious their status is: just as easily as they are elevated by him through various ethnic networks of appointments, so too can they be spurned and suffer public disgrace.

Clearly, the anusocracy rumours have to be seen against a complex background. On the one hand, they relate to an older discourse about witchcraft as a mystical source of wealth. But on the other they add new forms of secrecy in order to explain the spectacular enrichment of present-day elites that seems to surpass older parameters. All the people involved in these rumours - and in particular President Biya himself - are supposedly deeply involved in new networks of power of a more global allure, such as Freemasonry and Rosicrucianism. As already noted, these new associations reinforce the idea that homosexuality is a colonial imposition. However, in the Cameroonian case there are clear indications that the linking of transgressive sex to (illicit) enrichment has a longer history. But for this we have to go back in time more than a century.

\footnotetext{
${ }^{13}$ This station is owned by Amougou Belinga, who was also owner and publisher of L'Anecdote newspaper when it published lists of homosexuals in early 2006.
} 


\section{Tessmann: 'the King of the White Spot'}

The current anger in Cameroon about the baffling forms of enrichment by the new elites and their link to same-sex practices makes it interesting to go back to Günther Tessmann (1884-1969) and his descriptions of biang akuma (medicine of wealth) among the Fang - one of the Beti groups that now dominate the state - before colonial 'pacification'. It is even more interesting since, by relating this biang akuma to same-sex intercourse, he touches on a theme that seems to have a long history in other parts of the continent as well, even though it has received little attention until now.

Tessmann has become an almost mythical figure in Cameroon, since the reputation of his monograph Die Pangwe (The Fang) ${ }^{14}$ has to be balanced against its inaccessibility, as none of his work has been translated into French or English. In many respects he followed the German tradition set by figures such as Alexander von Humboldt (1769-1859) by combining the role of explorer, natural historian and ethnologist. Born in Lübeck, he left for Kamerun in 1904, at first to work for a plantation company. He soon set out on his own, in a most adventurous way, to collect plants and animals; later, ethnography became his major interest. On his return to Germany in early 1907, the Lübeck museum was so interested in his collection that it helped finance a special expedition that allowed Tessmann to work for two more years (1907-09) among the Fang. In 1913, after publishing Die Pangwe, he returned again to Kamerun, but now in the service of the government. During World War One, after the German defeat by a joint French and British invasion, he was interned together with the German army on the island of Fernando Pó, then a Spanish colony (present-day Bioko). Returning to Germany after the war, he published several monographs on other groups, among which the one on the Bafia was to play a special role in his interest in same-sex practices. However, he failed to get the academic recognition he felt his work entitled him to. After the Nazi regime excluded him from teaching, he migrated to Brazil in 1936, where he died in 1969. Nowadays, his Fang monograph in particular is a rare collector's item that fetches impressive prices on the antiquarian book market.

Tessmann developed an innovative way of doing fieldwork, not limiting himself to short visits but staying for longer periods in quite inaccessible places - something that was quite exceptional at the time. In his conception, such fieldwork had striking military overtones. At the various Forschungsstationen (research stations) that he successively built in the villages where he lived for months, the day started with a military parade of 'his boys'. He deemed a regular show of physical force necessary, not only against the people who worked for him but also against querulous neighbouring villages. Indeed, the title of his unpublished autobiography, König im weissen Fleck (King in the White Spot), reflects his obsession not only with 'white' or blank spots (which was one of the reasons why he

\footnotetext{
${ }^{14}$ Tessmann (1913). Tessmann saw the Fang as one group within the wider Pangwe group that, for him, also included the Bulu, Jaunde (Ewondo), Eton, Ntum and others. On this now somewhat ancient notion of Pangwe/Pahouin, see Alexandre (1965), who also spoke of a Beti-Bulu-Fang group. Since the rise to power of the current president, Paul Biya, in 1982, himself a Bulu, the term Beti has become the current one for this ethnic bloc.
} 
chose to settle in 'untouched' territory across the border with Spanish Guinea) but also with becoming a 'king' there. Thomas Klockmann, in his study of Tessmann's life and work, masterfully shows how this dream took shape (Klockmann 1988: 47ff.). Interestingly, he attributes a central role to one of Tessmann's assistants Max, a Batanga man from the coast whom Tessmann called his Minister and also his Gross-Wezir (grand-vizier). Indeed, a constant presence in Tessmann's stories about his work with the Fang is that of meine Jungen (my boys). Their identity may change (during the 1907-09 expedition two Jaunde men had a key role and were seconded by a larger group of local Fang boys), but Tessmann's ambivalent relation to them did not. He regularly disciplined them with an elephant whip but he also writes at length about the jokes he shared with them. The remarkable thing is that 'his boys' were apparently quite committed to him, several times saving his life by carrying him for days through the dense forest in order to get medicine for yet another attack of fever.

\section{Tessmann, same-sex practices and the 'medicine of wealth'}

For our focus on the theme of biang akuma (medicine of wealth) and its link with same-sex practices, it is important to stress the central role Geschlechtsleben (sexual life) had in Tessmann's interpretations, both in Die Pangwe and in his other monographs. For him it was the key to understanding people's Weltanschauung (world view), and thus it also indicated the 'phase' a society was in. Especially his later work among the Bafia (a group on the border between forest and savannah, some 150 miles north-west of the Fang) inspired him to introduce an opposition between Dualismus and Monismus as crucial for understanding the differences with the Fang. ${ }^{15}$ For Tessmann, this explained the contrast between the permissiveness with regard to same-sex practices among the Bafia, as representatives of an earlier 'monist' phase, and the complete refusal of such alternative sexual practices among the 'dualist' Fang.

But what of the notion of biang akuma (medicine of wealth) among the Fang? In Tessmann's Die Pangwe, it appears in various contexts and with various implications. It is first mentioned with quite negative overtones in relation to the Mekukmann (1913 [Part II]: 149), the evil sorcerer who kills people to use their skull as a mystical access to wealth. Later on (ibid.: 158), Tessmann notes, apparently with some surprise, that same-sex intercourse is related to such wealth medicines. He suggests as a possible explanation that the medicine, passed on by intimate touching, can bring prosperity to the two 'friends' (Tessmann's quotation marks) because of their mutual support of each other - all the more so since they are conscious of committing a sin and having to hide it.

Much later in Part II of the monograph, Tessmann returns to the topic in a section on 'Sexual deviations' (ibid.: 270-1), where he notes that, for the Fang,

\footnotetext{
${ }^{15}$ Around 1900 this conceptual opposition was seen by many as cutting edge (cf. the foundation of the Monistenbund - Monist League - by Ernst Haeckel in 1906 and its second president, Wilhelm Ostwald, announcing in 1911 that the new century would be the 'Monists' Century'). Monists defended a materialist, scientific view of the world (with Darwin as the great hero) against Christianity and its dualist views (spirit versus matter). During World War One, the Monistenbund rapidly lost its appeal. It seems that Tessmann applied a quite particular view of this distinction in his work, when it was already in decline (Seeck 1996).
} 
same-sex intercourse between adults is considered to be widernatürlich (against nature) and unerhört (unheard of). But he adds that it exists nonetheless, hidden under a Stachelkleid (prickly cover) that is none other than the biang akuma (wealth medicine). ${ }^{16}$ Here he expands on this link by recounting one of the Pangwe Maerchen (fairy tales) that play such a crucial role in his work as an ethnographic basis for audacious theorizing. Moreover, this particular tale acquired the status of a locus classicus in queer studies on Africa since it was translated and published in the Murray and Roscoe (1998) collection on traces of 'African homosexualities' in earlier literature. The story seems to be a simple one and can briefly be summarized as follows:

Four lovers went to the village of a beautiful girl. One of them eloped with her. Thereupon the second lover quarrelled with the girl's mother, killed her and went home. However, the third one went to the girl's father and told him that he wanted him instead of the girl:

'No, we shall always be together; when you piss, I shall piss as well; when you shit, I shall shit as well; when you sleep, I shall sleep with you on one bed. ${ }^{17}$

And so they did, but both soon died of yaws.

The fourth lover claimed the girl's brother and similarly slept with him in one bed, but they soon died of leprosy.

Thus retold, the story may seem quite flat (although with surprising turns), but it apparently lends itself to different interpretations. For instance, Murray and Roscoe in their interpretation of Tessmann conclude that the medicine of wealth is passed 'from the receptive partner to the penetrating partner' (1998: 142), while, in Tessmann's own text (reproduced in their collection a few pages later (ibid.: 156), the latter insists on mutuality, with both partners becoming rich (see above) - again, a signal that the link between anal penetration and enrichment allows for quite different interpretations that are crucial for what people mean when they denounce 'homosexuality'. Another complication is that the story's message is ambivalent. One can read it as 'proof' that same-sex practices - even if they were forbidden - were imaginable in Pangwe society; this is the way Murray and Roscoe propose to read it. Yet, the rapid - and horrible - punishment that followed for both same-sex couples also turns it into a severe warning against such behaviour. ${ }^{18}$

\footnotetext{
${ }^{16}$ Later, Tessmann would develop this idea of a Stachelkleid covering same-sex practices in a more flowery style: 'A casual traveller must get the impression that Homosexualität does not exist at all among the untouched Negroes. However, whoever stays longer on the spot and gets to know the land and the people knows under which heading homosexuality can be found. Among the Pangwe it is called "wealth medicine". Such wealth medicine offers a release to same-sex drives next to many mystical instincts. People believe that through the close connection mystical forces are passed on that make both partners rich' (Tessmann 1919: 133, translation by Peter Geschiere).

${ }^{17}$ Tessmann (1913 [Part II]: 273). In his monograph, Tessmann adds that for the Pangwe this fairly straightforward approach amounted to a grosse Liebeserklärung (declaration of deep love), as in the German phrase 'wo du hingehst will ich auch hingehen' (where you go, I will go as well).

${ }^{18} \mathrm{Cf}$. Tessmann (1919: 133), where he links the horrible illnesses that befall both couples to a revenge by the 'Ngi' - the secret cult to which he attributes a purificatory role in Pangwe society.
} 
Already in his monograph on the Fang, Tessmann signals his intuition that the dualist thinking that makes these people so tense in relation to Geschlechtsleben (sexuality) must have been preceded by an earlier phase. To his clear relief his later research (starting in 1914) with the Bafia confirms this intuition since they clearly exemplify this earlier phase. In his thesis on Tessmann, Thomas Klockmann (1988: 154) suggests that the Bafia research, and notably their tolerance of same-sex intercourse, marked a turning point in Tessmann's thinking about human evolution and the key role of sexuality in this evolution. He could work for only a few months with this group in its own habitat, since he started this project in mid-1914, just before the outbreak of World War One, which was to have such decisive consequences for Kamerun as well. But Tessmann is deeply struck by the radical differences with the Fang, and, again, for him Geschlechtlichkeit is the obvious gauge of these differences.

For the Bafia, Tessmann notes eine stark ausgeprägte Gleichgeschlechtligkeit (a marked homosexuality): 'For them it is completely the same for the evaluation of sexual exchange whether one loves a man or a woman ... No one has to dissemble because there are no radical contrasts in sexual exchange' (1934: 225, 260). Freundesliebe (loving a male friend) was completely acceptable among the Bafia, even among adults. Once, when Tessmann asked an informant whether he also practised this, the latter answered with a counter-question: 'Should I give up my people's custom?' - to the clear satisfaction of the ethnologist (ibid:: 226). Moreover, as was to be expected in Tessmann's view, this open sexual attitude corresponded to a world view that was radically different from that of die Pangwe. For the Bafia, the figure standing at the beginning of everything was not a one god, who abandoned his people after their fall from grace, but rather a Zauberer (sorcerer - in Tessmann's theories characteristic of an earlier phase), who, moreover, had mostly good intentions. Hence, there was not the pressure of binary oppositions (good/evil, man/woman) that burdened his Fang friends.

What should we think of Tessmann's almost lyrical passages on the relaxed acceptance of same-sex intercourse among the Bafia? Thomas Klockmann (1988: 152) somewhat drily remarks that Tessmann's main informants on this aspect were Bafia soldiers in the German Schutztruppen (colonial army) when they were interned on Fernando Pó after 1915. However, it would be wrong to assume that they were without women there. On the contrary, the German auxiliaries were accompanied by a following of women and children when they were forced to leave Kamerun (De Vries 2018). Moreover, some older friends told us that in their youth people used to gossip about the Bafia and their readiness to experiment sexually. Can we say then that Tessmann's cumbersome theoretical preoccupations - which clearly mark his Bafia monograph - did not stop him from noting real variations in everyday behaviour? ${ }^{19}$

Geschlechtsleben (sexuality) and especially Gleichgeschechtliches (homosexuality) may have a central role in Tessmann's work, but he remains remarkably brief on what forms it takes in practice. Apart from one discreet translation of the Bafia term for the sexual act between young adults - cohabitat [in] anum (intercourse into the anus?) - we did not find detailed indications of the form

\footnotetext{
${ }^{19}$ However, some Bafia now strongly contest Tessmann's views on their particularities in sexualibus.
} 
taken by sexual intimacies. For Tessmann, same-sex practices seem to be something to be studied at the level of discourse and not of practice. This is problematic since it is difficult to ascertain on what observations his references to same-sex practices are based. Subsequently, Tessmann's observations have been strongly contested, not only by Fang and other Beti people participating in present-day debates on homosexuality, but also by the academic authority Laburthe-Tolra. In his magnum opus on the Beti, this French anthropologist, who worked in the Beti area from the 1960s till the 1990s, strongly contradicts Tessmann on this point, claiming that Tessmann would have been fooled by the stories of his informants. ${ }^{20}$

Another anthropologist, Jean-Pierre Ombolo, himself a Beti, is equally radical in his denial of any trace of male homosexuality among his people. In his Sexe et Société en Afrique Noire (1990) - which is essentially a monograph on the Beti - he insists, like Laburthe-Tolra, that perversions sexuelles (sexual perversions) are always equated with sorcellerie (witchcraft). However, a quite different view comes from Séverin Cécile Abega, a brilliant anthropologist of a younger generation, also a Beti, who participated directly in the national debate triggered by the recent explosion of homophobia. ${ }^{21}$ For Abega, homosexuality had a special place in Beti culture since it related to a basic conception of the person as double. Often, one's double would be of one's own sex. But, for others, the double is of the opposite sex. People's perception of homosexuality would be based on this conception of the person as double (again closely related to the central notion of evu, witchcraft), and this would also explain the general unease with 'the homosexual' as a person who has the wrong double. So, here is a specific image of 'the homosexual', be it one that is about as heteronormative as possible: in this view, 'homosexuality is rationalized as the heterosexuality of doubles' (Abega 2007a: 104; see also Abega 2007b).

This view leads Abega to a somewhat dazzling enumeration of all the different ways in which this idea of a double allows same-sex intimacies to be related to wealth. As sexualite de luxe, it is generally attributed to the Grands, who impose same-sex intercourse on less fortunate people. This is why for quite some time in Cameroon homosexuals have been called francs-maçons (Freemasons) (Abega 2007a: 104). It is also why young men (and girls) who are successful are generally suspected of selling their sexual services. But the link can be made in an inverse sense too: the Grands are supposed to fortify their doubles by 'pumping the vital energy of the partner' (Abega 2007a: 105). However, such 'pumping' can also reinforce the passive partners, who will become slightly overweight (embonpoint) by absorbing the seed of their partners. Inversely again, someone who gets involved with a homosexual can become atrophied by his partner performing oral sex on him. Abega relates all these different variations to the general Beti perception of sexual intercourse as depleting one's vital energy. ${ }^{22}$

\footnotetext{
${ }^{20}$ See Laburthe-Tolra (1977: 912, 1243; 1985: 170-2). Laburthe-Tolra's radical critique on this point is striking since in other respects Laburthe-Tolra (who read German) had deep respect for Tessmann's work, especially for his study of secret societies.

${ }^{21}$ Sadly, Abega died in 2008, at only fifty-three years old.

${ }^{22}$ This is also a central motive in Ombolo's book on Beti sexuality quoted earlier; however, Ombolo related this only to heterosexual intercourse (1990: 104).
} 
In this cascade of possibilities, the striking thing is that the only fixed point seems to be the link between same-sex practices and enrichment (or energizing). There is no fixed division between penetrator and penetrated (or 'top' and 'bottom' to borrow from present-day jargon). Both partners can profit or lose through these intimate contacts. Just as in Tessmann's descriptions of biang akuma (medicine of wealth), the profile of 'the homosexual' remains volatile and open, except for the link people make with enrichment in whatever form. We will return to this openness that undermines any distinction between more specific sexual roles in analysing parallel conceptions elsewhere on the continent and also in more general literature.

\section{Same-sex practices and enrichment: examples from elsewhere}

The wider interest of Tessmann's work - and one of the reasons to dwell on it - is that the link he makes through biang akuma between wealth and same-sex practices can be found in many contexts throughout Africa, now and in earlier times. Apparently, this link has an obvious quality in African imaginaries on same-sex practices that is all the more notable since it is clearly not derived from the West. A few examples must suffice here (see also Geschiere 2017). In 1988, Quality, a Nigerian magazine, warned its readers in more general terms:

They [the homosexuals] are getting more and more aggressive and courageous by the day and are made up of the top brass in the society - successful lawyers, doctors, swanky businessmen, military men, ex-politicians, diplomats, and university graduates - all with a passion for men ... One bizarre yet interesting feature of homosexuality in the country is that it is cult-oriented and is making millionaires out of those who belong ... After every love session Quality learnt, the big shots who normally play the aggressor role, rush home keeping mum. At home they wash with some charms in a bowl and perform a ceremony ... its success is said to bring about a windfall of money. ${ }^{23}$

It is also interesting that this is not a new fad. It emerges, for instance, in a quite different garb in Ndèye Ndiagna Gning's fascinating thesis (2013) on des hommes aux identités sexuelles multiples (men with multiple sexual identities) in Senegal, where she refers to a long-standing prescription by marabouts (Muslim religious leaders) to rich men to have intercourse with another man in order to keep their fortunes. She also shows that such advice is related to Islamic scholarship from the eighteenth century. It is interesting how much this idea from Senegal resembles the 'hot' rumours that circulate on the Congolese music scene about the big stars of past and present generations, including Papa Wemba (a star of the recent past)

\footnotetext{
${ }^{23}$ Egbi (1988: 10-15) quoted in Johnson (2001: 139, 145). Epprecht (2006: 189) discusses a broad array of similar rumours - mainly from Southern and Eastern Africa - about chiefs trying to fortify their power against rivals; mine workers searching for protection against accidents; or boxers bracing themselves for their matches - all by acts of same-sex penetration. Compare also the now common association in many parts of the continent of 'homosexuals' with 'modernity'. This can again open up special routes to success. Graeme Reid (2013), for instance, relates the success of gay hairdressers in small-town South Africa to the aura of modernity they have for their clients. Often it is 'the ladies' who have to maintain their 'gents' (more masculine lovers).
} 
and Fally Ipupa (a current star), who are also supposed to be ordered by their nganga (healers) to undertake similar sexual transgressions in order to retain their popularity and their 'mystical' reputation. Artistic success in obtaining contracts and fame are attributed to imaginaries of sexual transgressions and sorcery (Hendriks 2017). ${ }^{24}$ People seem to take it for granted - as in the Senegalese and Nigerian examples above - that these celebrities take on the 'active' role in order to further empower themselves. ${ }^{25}$

However, to return to present-day Nigeria, there are also examples of quite different ways of linking the anus to wealth that are more in line with the pathways opened by Abega's enumeration of rumours in Cameroon. A striking example comes from the online journal Hype Nigeria: Nigerian Music and News (from 17 March 2017), which offers a long stream of confessions of and about people who needed to have their anuses stitched - some even three times - because they kept engaging in 'homosexualism'. The sordid details - about having to wear nappies ${ }^{26}$ because they could no longer contain their faeces - and the stream of medical details suggest that this belongs to a genre of 'confessions' that proliferate all over Africa with Pentecostalism. What is notable in these examples is that the reason why these 'repenters' took so long before stopping this painful behaviour is not lust but rather the riches these practices are supposed to generate. Sometimes, it is clear how riches are achieved - for instance, through the rewards offered by a Grand who imposes such penetration - but in other cases it is just the practice itself that is supposed to do the trick by allowing for an initiation into a 'cult', such as Freemasonry or Rosicrucianism.

Again, what is common to all these examples is the link with enrichment. But what is also common is that the sexual roles required for this show a kaleidoscopic diversity.

\section{The mysteries of the anus: from Africa to queer theory}

Can we distinguish recurrent patterns in this motley enumeration of situations in which the association of unproductive accumulation and anal penetration emerges? In line with the earlier signalled difference between Achille Mbembe's and Joseph Tonda's versions of this link, a contrast emerges between the anus as just a recipient and situations where it is attributed a more active role. Mbembe's version of the phallocrat subjecting even people of his own sex to anal penetration in order to appropriate their life force and to combat the decline of his own virility relates to a common theme in accusations of witcheraft

\footnotetext{
${ }^{24}$ See also, for example, 'Fally Ipupa et l'homosexualité, Oeil d'Afrique, 3 July $2012<$ https:// archives.oeildafrique.com/fally-ipupa-et-lhomosexualite/s, accessed 10 November 2018; 'Musique: le hip-hop congolais gagné par l'homosexualité', Congo Actuel, 3 January 2019 $<$ http://www.congoactuel.com/musique-le-hip-hop-congolais-gagne-par-lhomosexualite/>, accessed 20 May 2019. For an earlier scholarly discussion of rumours about these aspects of success in the Congolese cultural industry, see, for example, White (2007).

${ }^{25}$ See also Pierce (2016: 13) on the general worry in present-day Nigeria that the country is dominated 'by an elite class of lawless and lewd wealthy malefactors ... whose religion is witchcraft ... [with, as a consequence,] the prevalence of intertwined forms of immorality - crime, corruption, prostitution, homosexuality'.

${ }^{26} \mathrm{Cf}$. Meiu (forthcoming) on the symbolism of wearing nappies in Kenya.
} 
(Mbembe 2010; 2006). It leads to the depletion of the penetrated partner and is often illustrated with horrible stories about young men dying with their intestines hanging out because of such cruel practices. However, African imaginaries on sexuality are also beset by another powerful theme - that of sexual intercourse as depletion, as highlighted above by Séverin Cécile Abega and Jean Ombolo for the Beti, although it is much more general. In this view, it seems to be the passive partner who feeds on anal penetration. Placide Ondo (n.d.: 11), writing on the popular attacks on Gabonese President Ali Bongo, gives this line of thought an interesting twist: 'Se faire introduire un pénis pour être introduit dans les réseaux de pouvoir et d'enrichissement matériel [Allowing oneself to be penetrated by a penis in order to penetrate networks of power and material enrichment].' Ondo links this to Masonic rites and sees mysticisme animiste as closely related. For Joseph Tonda (2016: 134), this may bring apparent wealth but at the same time causes depletion of the life force (compare his Fanonist image of an impotent bourgeoisie, quoted above). Trying to understand the current rumours in Gabon about the wives of prominent men being horrified by the bloody nappies their husbands have to wear - think of the consternation in Nigeria about men having to have their anuses stitched, as noted above - he concludes that:

The emergence of the anus as source of material and political power for the class of feminized men makes the governing elite a class of consumers ... emptied of their 'energy' ... of their 'force' by the 'lodges' from the West. (Tonda 2016: 134) ${ }^{27}$

For Tonda, this 'sexualization of the anus' in present-day Africa recalls in a strange way Deleuze and Guattari's (1972: 270) characterization of capital as anus et vampire (anus and vampire).

An audacious leap might be helpful to see more clearly through this baffling array of opposing interpretations. To what extent can queer theory, which emerged in the West some forty years ago, offer some inspiration here? The leap might indeed seem audacious - African contexts are so different from EuroAmerican ones. But, as mentioned in the introduction to this article, there is a similar preoccupation with the anus - be it in a more positive sense. The dominant discourse in African contexts of anal penetration as depletion of the passive partner reminds us of the title of Leo Bersani's already quoted text 'Is the rectum a grave?' (2009 [1987]). However, Bersani, an American literary theorist using psychoanalytical insights, also offers a way out of this negativity. $\mathrm{He}$ wrote the text - now seen as a classic in queer studies - in 1987 at the full height of the AIDS crisis in the gay community in the USA. Anal penetration, which had become a focal point in the rapidly developing gay sauna culture, suddenly turned out to have deadly consequences. But Bersani insists that this should by no means imply a turning away from sex, nor to a search for 'displacement' (reconstructing sex as an expression of something else). ${ }^{28}$ Rather, he looks for a

\footnotetext{
${ }^{27}$ See also Hendriks (forthcoming 2021) on a band of young men in Congo celebrating the magical power of their anuses.

${ }^{28}$ As examples of such 'displacement', Bersani (2009 [1987]: 27-8) criticizes Jeffrey Weeks for reducing roles to social inequalities, and Michel Foucault for advocating the rituals of S\&M as a way of circumventing the ban on sexual promiscuity because of AIDS.
} 
solution by confronting the phallic implications of anal intercourse - top and bottom, mastery and subordination - and overcoming these through a 'redemptive reinvention of sex' (ibid.: 22). Intercourse does not have to be about overpowering; there is also 'the perhaps equally strong appeal of powerlessness, of the loss of control' - of succumbing to desire and 'losing sight of the self' (ibid.: 24). In such a vision, the rectum will no longer be a grave but rather a place for new beginnings. Ten years earlier - that is, before the outbreak of AIDS made sexual promiscuity so dangerous and stigmatizing - Italian philosopher, activist and theatre person Mario Mieli (2018 [1977]) launched in a somewhat different way a similar call to unleash the liberating effects of anal intercourse. For Mieli, a reevaluation of the anus and anal penetration was urgently needed for a 'liberation of Eros' - helping heterosexuals finally accept the homosexual element present in everybody - and this would bring about a truly revolutionary overturning of capitalism. ${ }^{29}$ In striking contrast to such rigid Marxist jargon is the playful way in which Mieli conveys the enjoyment that anal penetration can bring to both partners. This is what makes the book so attractive still today. Compare his battle cry quoted above: 'I hoard my treasure in my arse but my arse is open to everyone.' To which he adds:

If what in homosexuality especially horrifies homo normalis, that cop of the heterocapitalist system, is getting fucked in the ass, then this can only mean that one of most delicious bodily pleasures, anal sex, bears in itself a remarkable revolutionary force. (Mieli 2018 [1977]: 157)

Is there any relevance in confronting our African examples with these texts from Western queer theory? At first sight, it is especially the differences that are striking. The negative connotations of African discourses on anal penetration may correspond to Bersani's title equating the anus with a grave, but they certainly do not correspond to Bersani's 'redemptive sex project' for overcoming this negativity. And the desire that enlivens Mieli's book seems to be conspicuously absent from our African texts (which, of course, is not surprising, since we mainly quote from attacks on such 'homosexual' practices). Yet, on closer inspection, Bersani's and Mieli's passionate defence of anal penetration and sex in general as liberating and enriching may suggest another layer in the preoccupation in present-day Africa with the anus as a source of riches.

A recurrent theme in the rapidly growing stream of recent studies of same-sex arrangements in everyday life in Africa is the ease with which people combine different sexual roles - not only top/bottom in same-sex intercourse, ${ }^{30}$ but also across

\footnotetext{
${ }^{29}$ Clearly, the idea of an 'anusocracy' is not that foreign to Western thinking. Cf. also Mieli's reference (2018 [1977]: 179) to the title of an anonymous text 'Les culs émergumènes' ('The demonic assholes') published a few years earlier in Trois Milliards de Pervers: Grande encyclopédie des homosexualités (Three Billion Perverts: major encyclopedia of homosexualities), a special issue, edited by Felix Guattari, of the journal Recherches (published by Guy Hocquenghem and René Scherer, Paris, 1973).

${ }^{30} \mathrm{Cf}$. Hendriks (2017) on Congolese music stars who are supposed to play first the passive role as clients to earlier prominent singers and subsequently the active role in their relation to their younger successors. In Orock and Geschiere (forthcoming), we sketch the same alteration of roles that people now construe between leading figures in Cameroonian politics (AujoulatAhidjo-Biya).
} 
homo/hetero distinctions. This variability runs counter to the homophobic texts quoted above in which 'the homosexual' is seen as a specific and well-defined type. But studies on the everyday give a very different profile. In Graeme Reid's study (2010) of an explicitly gay Pentecostal church in Johannesburg in which the pastor preached that people have to follow their same-sex preference because clearly God made them that way, there is a constant worry about members - both young men and women - who stray by falling occasionally for the charms of the opposite sex, thus sinning against God's intentions for them. In Donald Donham's fascinating study (2018), West African men lodge their European (male) lovers on an upper floor added to their family house, with the wife and children living downstairs. Apostolos Andrikopoulos (2019) describes a young man living in a same-sex liaison in Nairobi and joking about his role as a 'housewife' but mentioning also that he can thus maintain a wife and children in the village. Ndèye Ndiagna Gning (2013), in her fascinating study of young men in Senegal experimenting with same-sex arrangements, characterizes them as 'men of multiple sexualities'. In the Kenyan anthology Stories of Our Lives, compiled by the Kenyan art collective The Nest in 2012-13 and bringing together life stories from 250 LGBTI Kenyans, many participants talk of sleeping with both men and women; characteristically, many of them are also reluctant to identify as gay or lesbian (van Klinken 2019). Of course, this recalls Tessmann's stories about Bafia taking it as self-evident that they had sex with both women and men.

In many of these stories, economic enrichment certainly plays a role. But often there seems to be more at stake: enjoyment, a taste for diversity and a talent for playing different roles. In a certain sense this diversity recalls the 'multiple selfrealization' principle that Jane Guyer (1993) highlights as characteristic of political-economic performance in many parts of Africa, and that Achille Mbembe in his 2016 Abiola Irele Lecture (Mbembe 2016) evokes as an opening for understanding how Africa's 'animist' heritage could function as an asset in the present global crisis. Guyer noted this talent for combining different forms of 'knowledge' as a stimulus for Africans in playing with new opportunities for enrichment. ${ }^{31}$ Africans who combine various sexual roles, as in the examples above, would similarly perform their sexuality in an enriching way. ${ }^{32}$ This may be a different kind of enrichment - even if it is also somewhat illicit - from the elite enrichment that is so furiously denounced by Cameroonians nowadays. Yet, one similarity is that this view of sexuality as enriching makes fixed boundaries seem to evaporate - in this context, those boundaries are homo or hetero as clearly delimited sexual 'identities'. In this sense, the African examples concur with Mieli's call for celebrating anal intercourse as bringing a liberation of Eros beyond a homo/hetero divide.

\footnotetext{
${ }^{31}$ In the article in which she introduced this notion, Guyer (1993) opposed 'accumulation' (the same on the same) to 'composition' (combining different assets): the first is characteristic of capitalism (money on money); the second would prevail, for instance, in big-men societies of West Central Africa where entrepreneurs can use all sorts of resources to profit from new contacts with the market economy.

${ }^{32}$ It may seem a big step from Guyer's political-economic version of such 'multiple self-realization' to people's experiments with sexual diversity, but Thomas Hendriks (2017) made a similar step - although with somewhat different implications - in his study of gay lifestyles in Kinshasa.
} 


\section{To conclude}

This text brings together elements from very different backgrounds: popular discourses in present-day Cameroon and elsewhere in Africa linking the supposed proliferation of 'homosexuality' to the involvement of national elites with Freemasonry and illicit enrichment; older ethnographic texts relating same-sex practices to enrichment in precolonial settings; African philosophers' interpretations of the current preoccupation with the anus as a source of wealth; and texts from Western queer studies that have already become classics in this field. Yet, despite all the differences, there is a connecting theme: the linking of same-sex practices to enrichment, whether in a purely material form or in a broader sense. Indeed, this linking of a transgressive form of sexuality to enrichment emerged from our material as a particular emphasis in many African contexts.

This linking has different implications. At first sight the link with Freemasonry suggests that homosexuality is a colonial imposition. And, indeed, today's opinion leaders use it as 'proof' that homosexuality is 'un-African'. However, the correspondence with older ethnographic data suggests that the link with enrichment has a longer history. As already noted, this should certainly not be taken as implying that the present-day excitement about Freemasons and their scandalous consumerist practices can be seen as merely signalling a 'traditional' continuity with practices the German ethnographer Tessmann noted among the Fang around 1900. Clearly, the association of same-sex practices with occult access to riches that turns up in so many places and at various times on the African continent has to be studied as being produced at the dynamic interface of modernity and tradition - not to be seen as separate poles, but inherently intertwined, producing one steaming mass of magma (to quote one of Joseph Tonda's (2005) more disquieting metaphors).

According to such a perspective, it becomes worthwhile to confront these African imaginaries with insights from Western queer studies. In the above, we have tried to show that, different as the contexts may be, such a confrontation can help bring out deeper layers hidden in this linking of anal intercourse to enrichment, thus going beyond the homophobic tenor that so strongly coloured the statements cited at the beginning of this article. The sombre overtones of queer reflections on the effects of AIDS on gay lifestyles - the rectum as a grave - are reflected in African complaints about an emerging 'anusocracy'. But Mieli's celebration of such sexual practices and Bersani's commitment to discover more positive openings in the sexual act itself correspond to forms of everyday conviviality that emerge from African ways of dealing with homophobic pressures. A striking trend in our African examples is people claiming space for forms of sexual diversity that allow them to go beyond the strict separation of homo/hetero as clearly delineated sexual 'identities'. Queer studies can help outline the originality of African stories of desire that risk remaining hidden under heavy homophobic discourse. But there are also implications in the reverse sense. These African stories seem to undermine what has become a shibboleth in Western sexuality studies (but only since the end of the nineteenth century): the idea that sexual practices express a sexual identity. Queer theory is still struggling to get away from this linking of practice to identity. Maybe African experiences can contribute to this? 


\section{Acknowledgements}

Many thanks to Francis Akindès, Apostolos Andrikopoulos, Patrick Awondo, Frank Beuvier, Donald Donham, Lars Frühsorge, Gert Hekma, Thomas Hendriks, Baz Lecoq, Achille Mbembe, Georges Meiu, Basile Ndjio, S. N. Nyeck, Katrien Pype, Graeme Reid, Michael Schütte, Rachel Spronk, Joseph Tonda and two anonymous Africa readers for comments on earlier versions. Rogers Orock acknowledges the support for his research from the American Council of Learned Societies (African Humanities Program Fellowship) and from the Fondation de la Maison des Sciences de l'Homme (Fernand Braudel Postdoctoral Fellowship 2015). In Paris, Rogers is especially grateful to Richard Banegas for hosting him at the Centre for International Studies (CERI) at Sciences Po Paris.

\section{References}

Abega, S. C. (2007a) 'La presse et l'état: l'exemple des procès sur l'homosexualité au Cameroun' in F. E. Boulaga (ed.), Dossier: l'homosexualité est bonne à penser. Special issue of Terroirs 1-2: 95-110.

Abega, S. C. (2007b) Les Violences Sexuelles et l'État au Cameroun. Paris: Karthala.

Alexandre, P. (1965) 'Protohistoire du groupe Beti-Bulu-Fang: essai de synthèse provisoire', Cahiers d'Études Africaines 5: 503-60.

Andrikopoulos, A. (2019) 'Kinship, same-sex erotic desires and options of mobility: the pursuit of respectability in Kenya, Ghana and beyond'. Paper presented at the American Anthropological Association conference, Vancouver, November.

Awondo, P. (2012) 'Médias, politique et homosexualité au Cameroun: retour sur la construction d'une controverse', Politique Africaine 126: 69-85.

Awondo, P. (2019) Le Sexe et ses Doubles: (homo) sexualité, politique, santé et société en postcolonie. Lyon: Presses de l'ENS Lyon.

Awondo, P., P. Geschiere and G. Reid (2012) 'Homophobic Africa? Toward a more nuanced view', African Studies Review 55 (3): 145-69.

Bersani, L. (2009 [1987]) 'Is the rectum a grave?' in L. Bersani, Is the Rectum a Grave and Other Essays. Chicago IL: University of Chicago Press.

Broqua, C. (2009) 'Sur les rétributions des pratiques sexuelles à Bamako', Canadian Journal of African Studies 43 (1): 60-82.

Corey-Boulet, R. (2019) Love Falls on Us: a story of American ideas and African LGBT lives. London: Zed Books.

Deleuze, G. and F. Guattari (1972) L'Anti-Oedipe: capitalisme et schizophrénie. Paris: Les Éditions de Minuit.

De Vries, J. (2018) 'Cameroonian Schutztruppe soldiers in Spanish-ruled Fernando Pó during the First World War: a "menace to peace"?', War and Society 37 (4): 280-301.

Donham, D. (2018) The Erotics of History: an Atlantic African example. Oakland CA: University of California Press.

Egbi, R. (1988) 'Men with a passion for men', Quality, 16 June.

Epprecht, M. (2006) "Bisexuality" and the politics of normal in African ethnography', Anthropologica 48 (2): 187-201.

Falola, T. (2003) The Power of African Cultures. Rochester NY: University of Rochester Press. 
Freud, S. (1905) Drei Abhandlungen zur Sexualtheorie. Leipzig and Vienna: Deuticke.

Geschiere, P. (1997) The Modernity of Witchcraft: politics and the occult in postcolonial Africa. Charlottesville VA: University of Virginia Press.

Geschiere, P. (2017) 'A vortex of identities: Freemasonry, witchcraft and postcolonial homophobia', African Studies Review 60 (2): 7-35.

Gning, N. N. (2013) 'Une réalité complexe: sexualités entre hommes et prévention du Sida au Sénégal'. PhD thesis, Université de Bordeaux Segalen.

Gueboguo, C. (2006) La Question Homosexuelle en Afrique: le cas du Cameroun. Paris: L'Harmattan.

Gueboguo, C. (2009) 'Penser les "droits" des homosexuels/les en Afrique: du sens et de la puissance de l'action associative militante au Cameroun', Canadian Journal of African Studies 43 (1): 129-50.

Guyer, J. I. (1993) 'Wealth in people and self-realization in Equatorial Africa', Man 28 (2): 243-65.

Hendriks, T. (2017) 'Queer(ing) popular culture: homo-erotic provocations from Kinshasa', Journal of African Culture Studies 31 (1): 71-88.

Hendriks, T. (forthcoming 2021) "Making men fall": queer power beyond antinormativity', Africa 91 (3).

Johnson, C. A. (2001) 'Hearing voices: unearthing evidence of homosexualities in precolonial Africa' in D. Constantine-Simms (ed.), The Greatest Taboo: homosexuality in black communities. Los Angeles CA: Alyson Publications.

Klockmann, T. (1988) 'Günther Tessmann - König im weissen Fleck: Das ethnologische Werk im Spiegel der Lebenserinnerungen'. $\mathrm{PhD}$ thesis, University of Hamburg.

Laburthe-Tolra, P. (1977) Mínlaaba: histoire et société traditionnelle chez les Bëti du Sud Cameroun. Paris: Champion.

Laburthe-Tolra, P. (1985) Initiations et Sociétés Secrètes au Cameroun: essai sur la réligion beti. Paris: Karthala.

Mbembe, A. (2001) On the Postcolony. Berkeley CA: University of California Press.

Mbembe, A. (2005) 'Leçons d'une chronique', Le Messager, 27 December.

Mbembe, A. (2006) 'Le potentat sexuel: à propos de la fellation, de la sodomie et autres privautés postcoloniales', Le Messager, 17 February.

Mbembe, A. (2010) Sortir de la Grande Nuit: essai sur l'Afrique decolonisée. Paris: La Découverte.

Mbembe, A. (2016) 'Knowledge futures and the state of the humanities'. Abiola Irele Lecture delivered at the 59th Annual Meeting of the African Studies Association, Washington DC, 1-3 December.

Meiu, G. P. (forthcoming) 'Diapers and the under-layers of citizenship: queer objects, intimate exposures and the rescue rush in Kenya', Cultural Anthropology.

Mieli, M. (2018 [1977]) Towards a Gay Communism: elements of a homosexual critique. Translated by D. Fernbach and E. C. Williams. London: Pluto Press. Originally published as Elementi di Critica Omosessuale. Turin: Einaudi.

Moore, H. L. and T. Sanders (eds) (2001) Magical Interpretations and Material Realities: witchcraft and the occult in postcolonial Africa. London and New York NY: Routledge.

Murray, S. D. and W. Roscoe (eds) (1998) Boy-wives and Female Husbands: studies in African Homosexualities. New York NY: Palgrave. 
Ndjio, B. (2012) 'Postcolonial histories of sexuality: the political invention of the libidinal African straight', Africa 82 (4): 609-31.

Nuttall, S. (2004) 'Stylizing the self: the Y generation in Rosebank, Johannesburg', Public Culture 16: 430-52.

Nyeck, S. N. (2013) 'Mobilizing against the invisible: erotic nationalism, mass media, and the "paranoid style" in Cameroon' in S. N. Nyeck and M. Epprecht (eds), Sexual Diversity in Africa: politics, theory, citizenship. Montreal and Kingston: McGill-Queen's University Press.

Ombolo, J.-P. (1990) Sexe et Société en Afrique Noire. Paris: L'Harmattan.

Ondo, P. (n.d.) 'L'irrévérence politique ou le pillage symbolique du chef de l'état gabonais: le drame d'une succession non liquidée'. Unpublished paper.

Orock, R. and P. Geschiere (forthcoming) 'Decolonization, Freemasonry, and the rise of "homosexuality" as a public issue in Cameroon: the return of Dr Aujoulat', African Affairs.

Pierce, S. (2016) "“Nigeria can do without such perverts": sexual anxiety and political crisis in postcolonial Nigeria', Comparative Studies of South Asia, Africa and the Middle East 36 (1): 3-20.

Reid, G. (2010) Above the Skyline: Reverend Tsietsi Thandekiso and the founding of an African gay church. Pretoria: UNISA Press.

Reid, G. (2013) How to Be a 'Real Gay': gay identities in small-town South Africa. Pietermaritzburg: University of KwaZulu-Natal Press.

Roxburgh, S. (2019) 'Homosexuality, witchcraft, and power: the politics of ressentiment in Cameroon', African Studies Review 62 (3): 89-111.

Seeck, A. (1996) 'Wilhelm Ostwald, Monistenbund, Energie und Sexualwissenschaft', Mitteilungen der Magnus-Hirschfeld-Gesellschaft 22 (3): 67-97.

Tessmann, G. (1913) Die Pangwe. Berlin: Wasmuth.

Tessmann, G. (1919) 'Die Homosexualität bei den Negern Kamerun', Jahrbuch für Sexuelle Zwischenstufen 1-2: 121-38.

Tessmann, G. (1934) Die Bafia und die Kultur des Mittelkamerun-Bantu. Stuttgart: Strecker \& Schröder.

Tonda, J. (2005) Le Souverain Moderne. Paris: Karthala. Translated by C. Turner as Modern Sovereign: the body of power in Central Africa. Delhi and Chicago IL: Seagull Books, 2020.

Tonda, J. (2016) 'Fanon au Gabon: sexe onirique et Afrodystopie', Politique Africaine 143: 113-37.

van Klinken, A. (2019) Kenyan, Christian, Queer. University Park PA: Penn State University Press.

Warnier, J.-P. (1993) L'Esprit d'Entreprise au Cameroun. Paris: Karthala.

White, B. W. (2007) 'La quête du lupemba: rumeurs, réussite et malheur en République démocratique du Congo', Sociologie et Sociétés 39 (2): 61-77.

\begin{abstract}
Cameroonians recently invented a new word to characterize the state of their country: anusocratie (the rule of the anus). This became central in the moral panic from 2000 onwards over a supposed proliferation of homosexuality. Anusocratie links such same-sex practices to illicit enrichment by the national
\end{abstract}


elites and their involvement with secret associations of Western provenance, such as Freemasonry, Rosicrucians and the Illuminati. This article tries to unravel this conceptual knot of homosexuality, the occult (Freemasonry) and illicit enrichment: first, by historicizing it. Of interest in the Cameroonian case is the fact that a similar link is mentioned in one of the first ethnographies, Günther Tessmann's Die Pangwe. Freemasonry is clearly a colonial imposition on the country, but the link between same-sex practices and enrichment has a longer history. Second, a comparison with similar ideas elsewhere on the continent can also open up wider perspectives. The link with illicit enrichment does not figure in classical conceptions of 'homosexuality' as developed in Europe, yet it strongly emerges from examples from all over Africa. Both Achille Mbembe and Joseph Tonda show that this image of the anus - anal penetration - articulates popular concerns about staggering inequalities. Yet, this aspect is ignored in debates about growing 'homophobia' in Africa. A confrontation with classical texts from Western queer theory (Bersani, Mieli) can help us discover other layers in African discourses, notably an emphasis on sexual diversity as an answer to homophobia. It can also serve to relativize the linking of sexual practices to sexual identities, which is still seen as self-evident in much queer theory of Western provenance.

\section{Résumé}

Les Camerounais ont récemment lancé un nouveau terme pour caractériser l'état du pays : 'anusocratie' ('le gouvernement de l'anus'). L'idée jouait un rôle central dans la panique morale depuis 2000 à cause d'une prolifération supposée de l'homosexualité. 'Anusocratie' relie des pratiques même-sexe à l'enrichissement illicite par l'élite nationale et son implication profonde dans des associations secrètes de provenance du Nord, comme la Franc-maçonnerie, le Rosicrucianisme et les Illuminati. Notre article essaie de dénouer le nœud dans l'épistémologie populaire de l'homosexualité, l'occulte (Franc-maçonnerie) et l'enrichissement illicite. D'abord en le historicisant. Un intérêt spécial du cas camerounais est qu'un lien similaire figure dans une des premières ethnographies, Die Pangwe par Günther Tessmann. La Franc-maçonnerie a été sans doute une imposition coloniale sur le pays, mais le lien entre homosexualité et enrichissement a une histoire plus longue dans la région. Deuxièmement, une comparaison avec des idées similaires ailleurs dans le continent peut aussi ouvrir des perspectives plus larges. Le lien avec enrichissement illicite ne figure pas dans les conceptions classiques de l'homosexualité comme elles ont été développées en Europe au 19ème siècle, mais il émerge clairement des exemples de partout en Afrique. Achille Mbembe et Joseph Tonda ont montré tous les deux que cet image de l'anus - et de la pénétration anale - exprime des préoccupations populaires sur des inégalités inédites et croissantes. Pourtant cet aspect est ignoré dans les débats courants sur l'intensification récente de l'homophobie sur le continent. Une confrontation avec des textes classiques des queer studies occidentaux (Mieli, Bersani) peut servir à déceler d'autres tendances dans des discours africains. Cette confrontation peut servir aussi à relativiser l'équation des pratiques sexuelles aux identités sexuelles qui paraît toujours aller de soi dans maints énoncés des queer studies de provenance occidentale. 